\section{Building, inhabiting and "perceiving" private houses in early medieval Italy}

\section{La manera de construir, habitar y percibir las casas particulares de la alta Edad Media en Italia}

\section{Giovanna Bianchi*}

Dipartimento di Scienze storiche e Beni Culturali.

Università degli Studi di Siena (Italia)

\begin{abstract}
The first part of the article sums up the evolution of the subject of private houses and homes in Italian historiography, beginning mainly in the 1970s, when scholars began to take an interest in this subject, also thanks to the development of the modern discipline of Medieval Archeology. After identifying current lines of research, the second section analyzes the main kinds of dwellings, their geographical distribution, and their various chronologies. The third section goes on to discuss the issue of how these residential buildings were the product of particular technical skills, analyzing the characteristics of the knowledge of the people who built them, in some cases also attested to in written sources. The fourth section seeks to link specific choices of construction solution to the socio-economic context of the time, trying to establish a connection between the type of buildings that were built, the kind of life their inhabitants led, and the contemporary mentality. The last section is dedicated to a sort of final synthesis, with a brief, further examination of the various issues dealt with in the article as a whole.
\end{abstract}

Key words: Private homes; Italy; early medieval period; archeology of architecture; technical skills; ways of living.

\section{Resumen}

La primera parte del artículo hace un resumen de la evolución de las casas particulares y viviendas domésticas en la historiografía italiana a partir de los años 70, cuando los estudiosos empezaron a interesarse por el tema y también gracias al desarrollo de la disciplina moderna de arqueología medieval. Tras identificar las actuales líneas de investigación, la segunda parte analiza los principales tipos de vivienda, su distribución geográfica y diversas cronologías. La tercera aborda el concepto de las viviendas residenciales como el resultado de determinadas habilidades técnicas y analiza las características del conocimiento del pueblo que las levantó, corroborando algunos casos con fuentes documentales. La cuarta parte intenta encontrar una relación entre las decisiones tomadas en determinadas soluciones constructivas y el contexto socioeconómico de la época, con el fin de establecer una conexión entre la tipología de las viviendas, la vida de sus moradores y la mentalidad de la época. El último apartado ofrece un resumen final con un breve repaso a los temas abordados en el artículo.

Palabras clave: Viviendas particulares; Italia; alta Edad Media; arqueología de la arquitectura; conocimientos técnicos; modos de vida.

*giobianchi@unisi.it

\section{EARLY MEDIEVAL HOUSES. EVOLUTION OF A HISTORIOGRAPHICAL ISSUE}

In Italy, the analysis of private residential dwellings in the early medieval period is one of the questions least studied by historians studying written sources and material evidence. This has been true up until the last few decades of the last century. For much of the 20th century, archeologists focused their attention mainly on investigating major public monumental complexes (especially religious complexes), or necropolises. By contrast, despite dealing with important themes such as the birth and formation of the medieval city, and castles, generations of historians often neglected the study of the material aspects of these sites, concentrating more on the historical and institutional aspects, in accordance with a historiographical tradition that is well-established in our country (Gelichi 1997).

The lack of interest was partly due to the inability of archeologists to record the fragile remains left on the ground by dwellings, especially when built of perishable materials, given the unsophisticated investigative tools available at the time. Precursors of this kind of study are very few, and they are worth mentioning. After a chance find of early medieval huts by the famous paleo-ethnologist Pigorini, at the end of the 19th century, in the 1960s, at the Castelseprio excavation (fig.1), carried out by a Polish team under Tabaczynski, a building in mixed materials was brought to light that is interpreted as one of the houses of the Lombard area ${ }^{1}$.

Documents were the main sources for the contributions of Michelangelo Cagiano de Azevedo (published in Fonseca, Adamesteanu, D'Andria 1986), who was the first researcher, in the 1960s and '70s, to dedicate specific attention to the various different kinds of early medieval buildings, despite the fact that his research only attached secondary importance to material evidence. He was also responsible for a cursory publication, in 1976, of two wooden huts, excavated at the site of Bagnoregio (Viterbo) dating between the end of the 7 th and the start of the 8th centuries, and ascribed, on the basis of their typology, and especially on the basis of the simple building materials, to Lombard peoples, in line with a clear ethnic interpretation (Cagiano De Azevedo 1986a, pp.391-394).

However, only in the mid-'70s, when a modern discipline of Medieval Archeology developed in Italy, was there a major leap forward in the study of this subject. There were several reasons for this: the increasing spread

\footnotetext{
${ }^{1}$ For a more detailed chronological history of historiographical research, see Santangeli Valenzani 2011, pp. 9-14.
} 


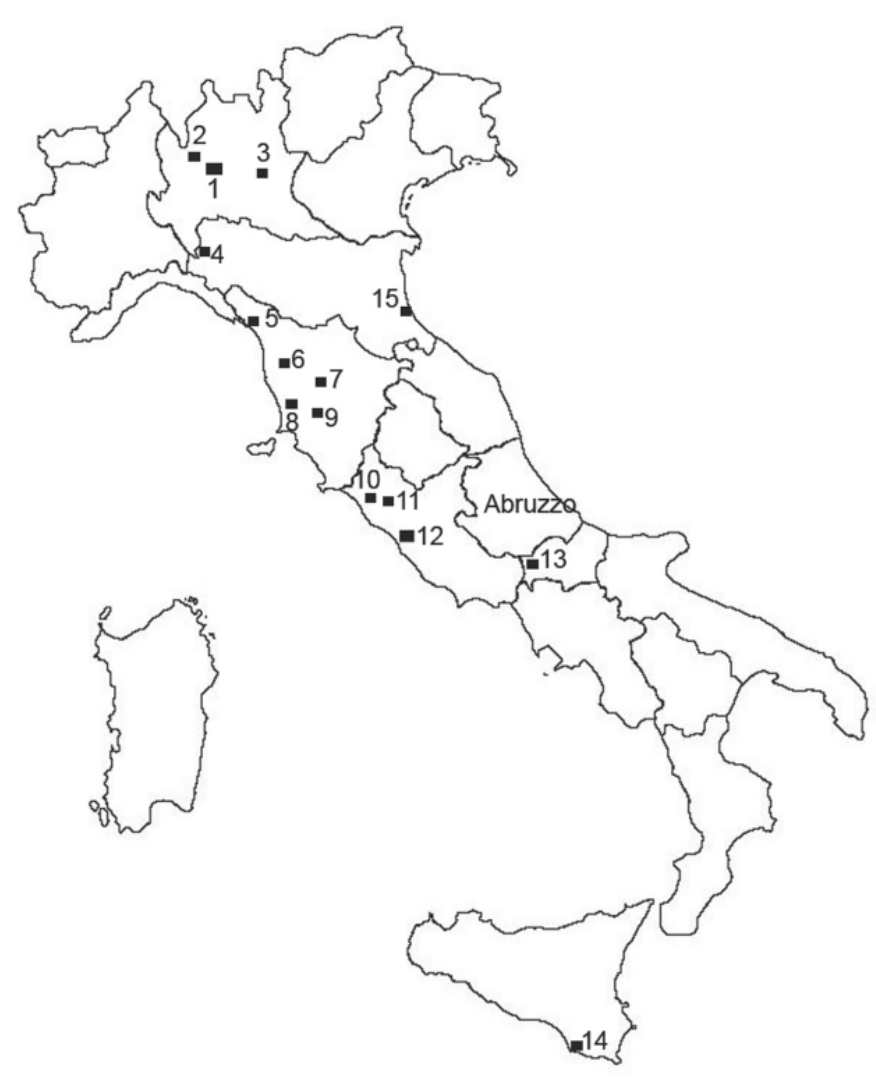

Fig. 1. Location of some of the towns and sites mentioned in the text: 1 Milan; 2 Castelseprio; 3 Brescia; 4 Bobbio; 5 Luni; 6 Lucca; 7 Poggibonsi; 8 Donoratico; 9 Montemassi; 10 Tuscania; 11 Viterbo; 12 Rome; 13 S. Vincenzo al Volturno; 14 Caucana; 15 Ravenna-Classe

of the method of stratigraphical analysis; the formation of that discipline which is today known as the archeology of architecture, which developed within medieval archeology; and the importance which studies of material culture began to have, in common with other countries in Europe (Gelichi 1997). Since then, the analogy of processes of stratification, and the production of an elevation, began to be placed on the same footing as those of any other type of archeological artefact, and forms of architecture became an important parameter in studying material culture. The main area of investigation in those years was abandoned villages (the most recent example being Comba 2011). While on the one hand this allowed a study of forms of settlement in their material aspects within a broader, concrete geographical space, on the other hand it led to attention being focused above all on stone-built houses, and the middle centuries of the medieval period. Despite the find in the 1970s of buildings in perishable materials at some of the rural sites investigated by the Genoa Research Group, under Tiziano Mannoni (Gruppo Ricerche Genova, 1974a, 1974b), the first, pio- neering contributions to the archeology of architecture by Mannoni himself and by his collaborators thus concentrated on this latter building type. Subsequently, methodological tools were perfected to concentrate primarily on an analysis of building techniques in stone and brick (Mannoni, Poleggi 1974; Mannoni 1976). Between the end of the 1970s and the start of the following decade, early medieval structures made of perishable material, interpreted as homes, were found at other sites investigated archeologically in Italy (fig. 1), for example Santa Maria in Civita (Barker, Hodges, Wade 1980) and the hill of San Pietro, Tuscania (Andrews 1978). While the first syntheses were starting to be published, in other European countries, of residential buildings in this period, it was another British archeologist, Brian WardPerkins, who published two wooden houses excavated in the forum of the city of Luni (fig.1), dating to the 6th century (Ward-Perkins 1981; 1985).

Later on, with the start of the important urban excavation campaigns in northern Italy (Brogiolo 1984), the number of perishable structures, which can be interpreted as dwellings, grew exponentially, in parallel with the discovery of similar structures on hill-top sites in Tuscany in southern-central Italy (Francovich 1985, Francovich, Milanese 1990). Despite this, these discoveries did not usher in a branch of study devoted specifically to residential buildings. Instead, they were used as material indicators in the wider historiographical debate in those years, in relation to continuity and discontinuity of ancient towns, in an urban setting, and as evidence of centralized settlement phases, prior to castles.

In 1992, at the important conference organized in Siena by Francovich and Noyé, dedicated to early medieval archeology, the subject of residential constructions was only marginally discussed, since the only two papers on the subject focused on an analysis above all of construction techniques (Galetti 1994; Parenti 1994).

In 1993 residential buildings were the central theme of a conference held at Monte Barro by Gian Pietro Brogiolo (Brogiolo 1994). On that occasion, as well as presenting several regional cases relating to northerncentral Italy, Brogiolo's contribution summed up guidelines for the future research agenda. Following in the footsteps of the previous work by Mannoni on stone buildings, the following areas were identified as the main parameters of study: the technology of construction, the organization of building work, types of dwellings and their function, and their connection with socio-economic aspects. 
In subsequent years, construction technology was certainly the aspect given most attention, and this was the main question on which the first archives were formulated regarding constructions in perishable material. These archives began to be compiled in the mid-1990s, by the Siena group, directed by Francovich (Fronza, Valenti 1996).

Residential buildings in urban contexts, with reference to their functions and possible socio-economic meanings, were given important chapters of their own in the first work summarizing archeological research carried out up until that time, written by Gian Pietro Brogiolo and Sauro Gelichi (Brogiolo, Gelichi 1998).

In the same years, important contributions were also published by Paola Galetti, in which the subject of living in the early medieval period was discussed by setting out mainly from an analysis of documentary sources, albeit with constant attention to the results of more recent archeological research (Galetti 1997).

Over the last 20 years, the multiplication of research, especially in rural parts of Italy, has led to a gradual reduction of the divide separating Italy from research in other European countries on this issue. In 2011 the first monograph appeared on residential buildings in our period. However, although the content was excellent, owing to the nature of the publication (a series of brief manuals designed for university teaching) it primarily contained the main overviews on these issues (Santangeli Valenzani, 2011). Accordingly, we still do not have a more detailed archeological study for the whole context in Italy nationwide.

Notwithstanding this, the more recent mass of studies which can be related to limited cases or specific geographical areas offers the possibility of seeing trends under way. Today, research is generally geared towards moving beyond a number of interpretational approaches followed in the past by some scholars, such as the research which ascribed to this period construction techniques and modes of domestic living which differ between the Byzantine and Lombard areas, as well as simplified production cycles (both in wood and stone), and elementary building mod$\mathrm{els}^{2}$. Many medieval archeologists are concentrating ever greater attention on higher-prestige architecture, often built of non-perishable materials, and commissioned by

\footnotetext{
${ }^{2}$ As well as the early work by Cagiano de Azevedo, in some of the first studies of urban construction sites there was an initial tendency to accentuate the aspect of the simplification of production cycles, and completed buildings, to reinforce the aspect of discontinuity between the ancient town and the early medieval town.
}

higher-status individuals, both secular and religious. At the same time, the fact that interest is shifting increasingly toward the centuries that mark the transition between Late Antiquity and the early medieval period has led to the compilation of important syntheses on ways of constructing, including in stone, relating to this period. In parallel, a firm awareness has developed of the need for an interdisciplinary approach, to thoroughly understand the structure of an early medieval building site, marked by very different dynamics from those of the middle centuries of the medieval period. The most recent research, which is gradually tending to fill the gap with regard to our understanding of these issues in southern Italy, allows a greater chronological overview of the sequence of the various forms of dwellings, especially in the case of some centuries, specifically from the 9th to 11th centuries, which were previously often marked by an archeological record that was all too lacking.

Despite the fact that most of these studies still focus on documentation of the main building techniques, in relation to the organization of actual building work, and the political and economic dynamics connected with that organization, many other works also address more complex aspects. These include an accent on specific building types and their respective functions, with renewed interest, in recent years, towards the following themes: their ethnic connotations; an analysis of these types, in relation to the different forms of settlement, and the general residential fabric of sites; and their connection with the various forms of social hierarchies and the establishment of new political powers.

By contrast, compared to the European panorama, there are still too few studies linking forms of domestic dwellings with their differing respective social structures, and changes in mentality or ways of living.

We will refer to the research of the last few years for the general summaries in subsequent paragraphs.

\section{BUILDING HOUSES: THE MAIN BUILDING TYPES, IN THE LIGHT OF THE MOST RECENT ARCHEOLOGICAL RESEARCH}

As we will note here and in subsequent paragraphs, there is an extremely varied range of types of houses in Italy, not only in individual local geographical contexts but also within each settlement itself, however large or small.

Archeologists who have recently tried to identify the main building types have done so with reference primarily to the material used in construction (Valenzani 2011; Brogiolo 2008; Brogiolo 2009). 

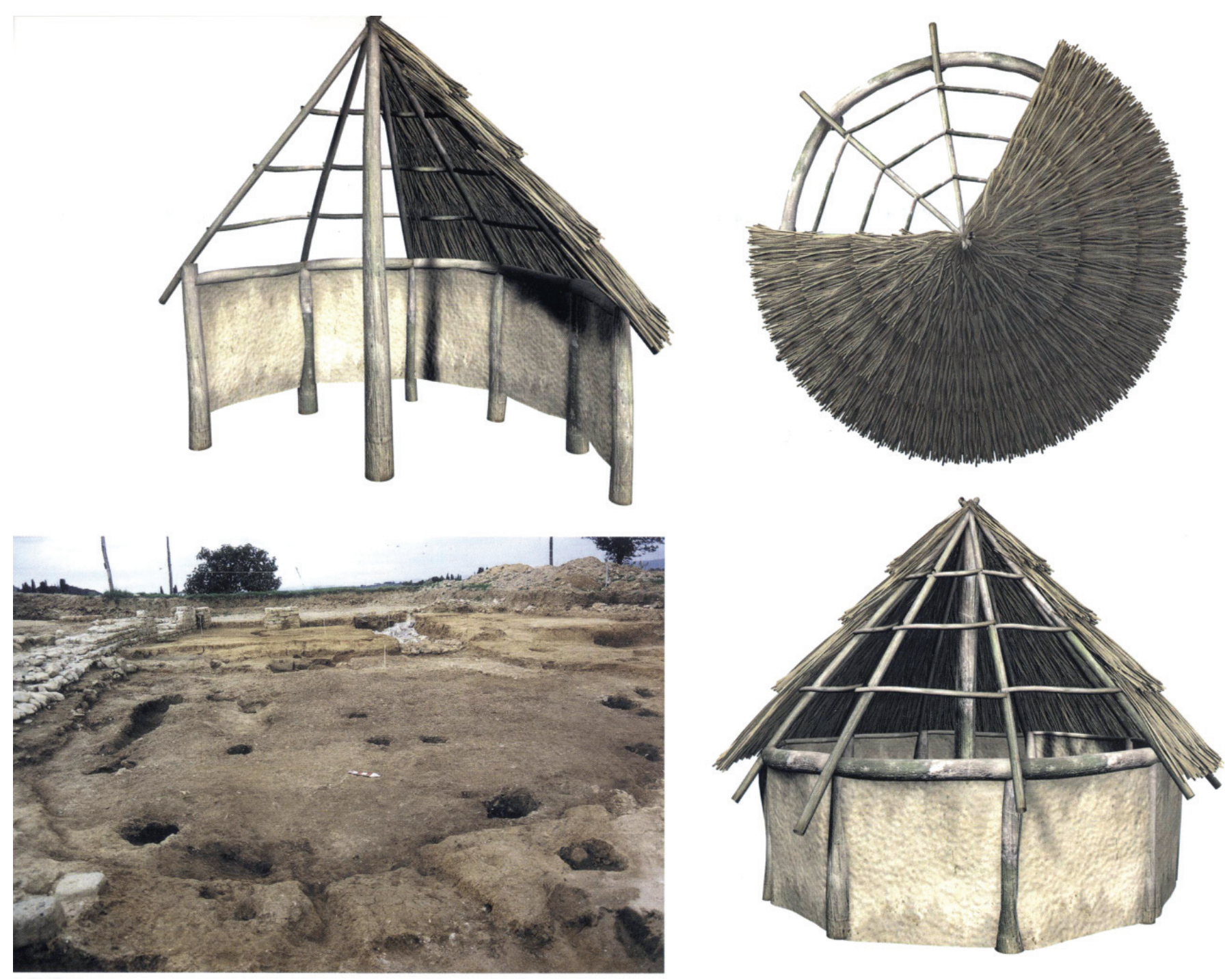

Fig. 2. Example of a hut with a framework of wooden poles fixed into the ground, from the Poggibonsi site (from Valenti 2004, p. 28, fig.10)

In excluding from this analysis homes dug into the actual rock $^{3}$, residential buildings were initially divided into three main groups: wood-built constructions; mixedmaterial constructions, using both perishable and nonperishable materials; and stone-built constructions, or reused non-perishable material.

Within these three groups, attempts have been made to identify sub-groups, setting out from the construction technique.

In the case of wood, the most frequent type, from northern Italian to southern Italy, is a house built using vertical posts, sunk into the ground (fig. 2). The most

${ }^{3}$ This type is especially present in south-central Italy. Studies of this type are connected to a complex series of problems, the main problem being their exact chronology which, for reasons of space, cannot be discussed exhaustively here. For a recent view, see De Minicis 2008 and Santangeli Valenzani 2011, pp.117-128. common plan is a rectangle, which can be bigger or smaller, although there is no lack of examples of houses of this type that are square or circular in plan. The space between the poles was filled with a system of woven vegetable matter covered with clay, or, or more rarely, with flat wooden boards. The technique of a main structure comprising wooden poles is attested at numerous urban and rural sites in Italy, as of the 5th century, although it was more widespread from the 6th-7th centuries up until the middle centuries of the Middle Ages, and afterwards too. In this kind of house, the floor usually consisted in beaten earth, in which there was often a hearth. When there were internal divisions, it is possible that different areas were used for different purposes, although there was a large degree of overlap between domestic and working spaces, and areas for keeping animals. 


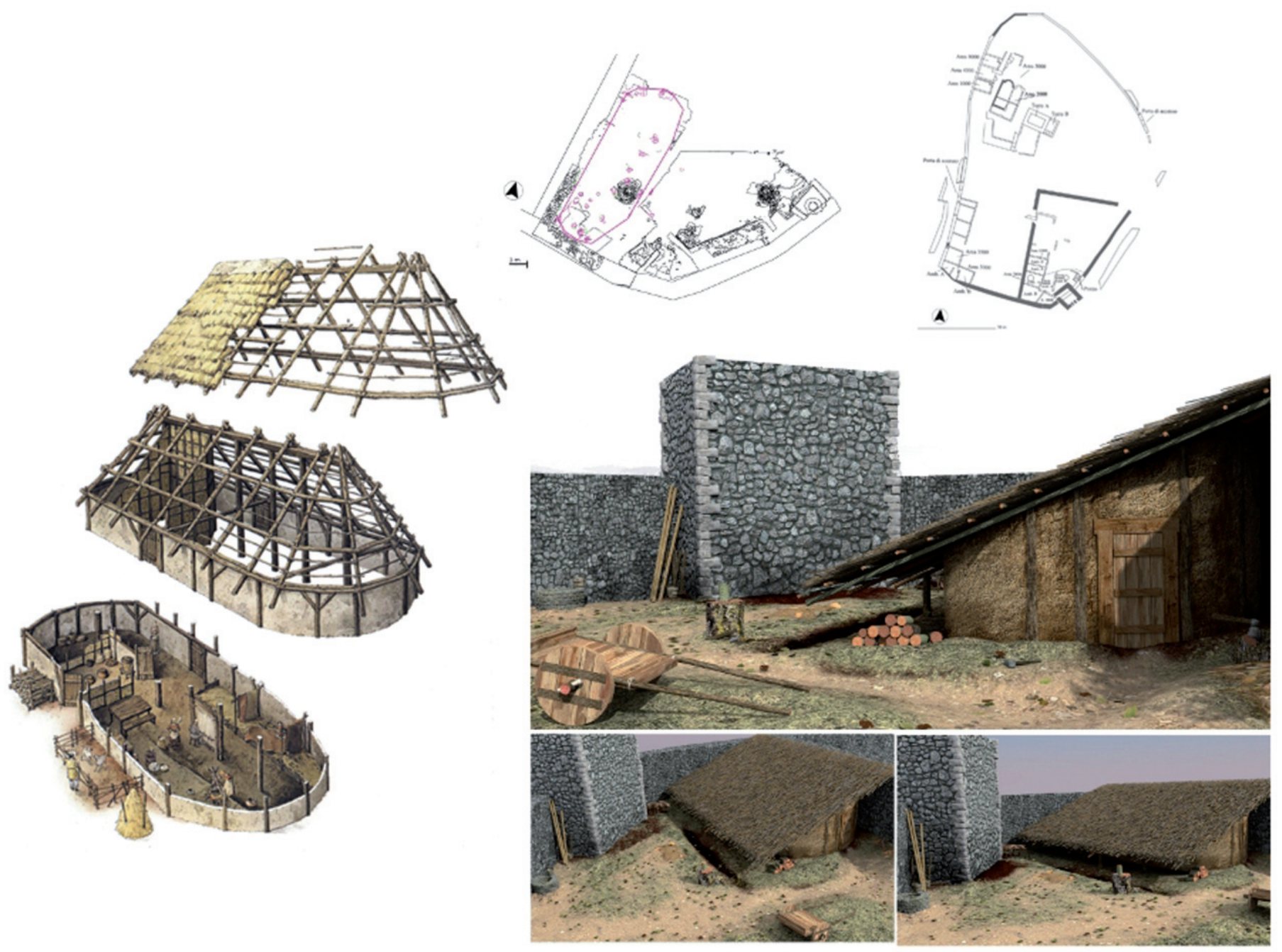

Fig. 3. On the left, a reconstruction of the Poggibonsi hut (from Valenti 2004, p.31, fig.13). On the right, the plan of the site and hut at Donoratico, with reconstruction, also including the stone tower.

Also belonging to this overall group are two unique examples of large huts, comparable in their plan to the longhouses in the Germanic area and northern Europe. These structures have been found in Tuscany at the rural sites of Poggibonsi and Donoratico, both open to interpretation as the power centre of a curtis (fig. 3). The large hut at Poggibonsi (Valenti 2004; Valenti 2007) was elliptical and was supported by a framework of posts fixed into the ground. Its large size $(17 \times 8.5 \mathrm{~m}, 144 \mathrm{sq} \mathrm{mt})$ and the kind of animal bone finds and pottery, suggested to the excavators that it should be interpreted as the place of residence of an overseer acting on behalf of the estate owner, with the task of supervising agricultural activities at the site, in the context of the obvious hierarchical relationship between the residential spaces. It was apparently frequented in a period between the second half of the 9th century and the beginning of the following century (Valenti 1996, p.376;
Valenti 2007, pp. 107-114). The hut at Donoratico (Bianchi et alii 2012), divided internally into two «naves», had a similar plan $(18 \times 7 \mathrm{~m}, 126 \mathrm{sq} \mathrm{mt})$, although its outer walls were supported by vertical posts which in some places rested on a low stone socle. The material culture evidenced by the finds in this hut, when compared to the other contemporary dwellings at the site, the presence of many spindle-whorls and thus probably of a loom, along with several hearths and a grinding stone for grinding flour in the living quarters, leads to an interpretation of this is a building possibly used for temporary communal habitation, given the craft activities which took place in it. It is suggested that it was built towards the end of the 9th century, or the beginning of the following century, and thus after the fall of Carolingian power. The hut stood within a space delimited by a stone surrounding wall, which defined a reserved area within the settlement itself, 


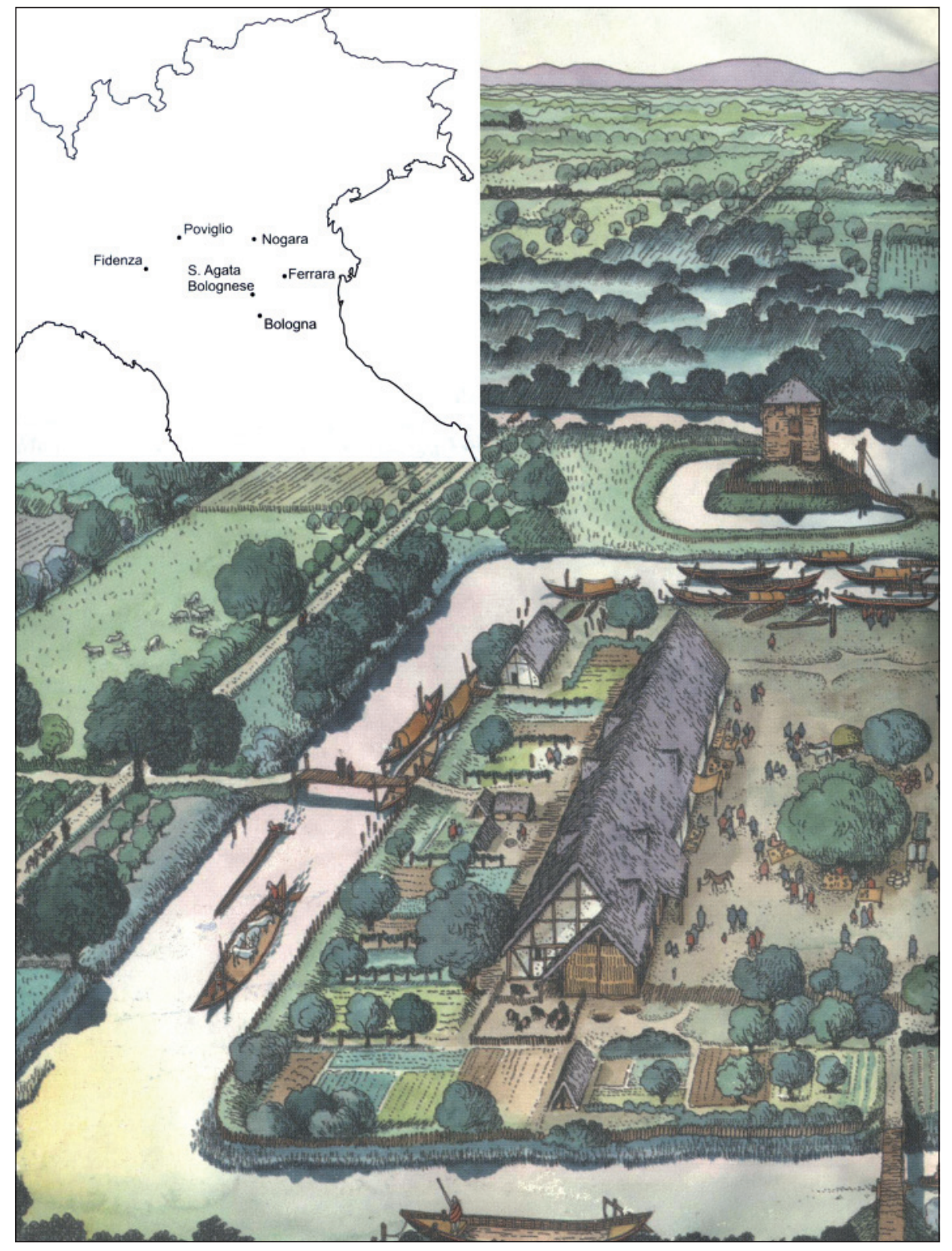

Fig. 4. Reconstruction of the village near S. Agata Bolognese (from Gelichi 2003): in the top left, the location of the sites mentioned in the text as displaying the technique of horizontal beams around the perimeter (from Gelichi, Librenti 2010, p.16, fig.1) which in turn was encircled by an outer wall. Close to the hut there was a stone tower (which we discuss below) which was probably reserved for the authority that controlled the overall site. This large structure in Donoratico is contemporary with important transformation works which were seen at this and other hilltop settlement sites in southern Tuscany, and which can be attributed to the actions of important political players which here, and at other sites, involved the construction of the first stonebuilt outer defensive walls (Bianchi 2010a).

In addition, at the end of the 9th century and above all in the 10th century, there is a very clearly defined distribution of another sub-group of residential structures, all relating to a consistent geographical area. These are houses where, instead of being fixed directly into the ground, the vertical, load-bearing posts were located within, or rested on, horizontal beams which followed the perimeter of the structure (fig.4). The vertical posts, or beams, were connected together by walls consisting in wooden boards, in line with a type of construction which has very many points of comparison with contemporary structures in the Franco-German area, and in northern Europe generally (Saggioro 2010; Gelichi Librenti 2010). This building style spread to northern and central Italy, both in urban areas (Ferrara, Fidenza and Bologna), and in rural areas (S.Agata Bolognese, and Poviglio and Nogara). 


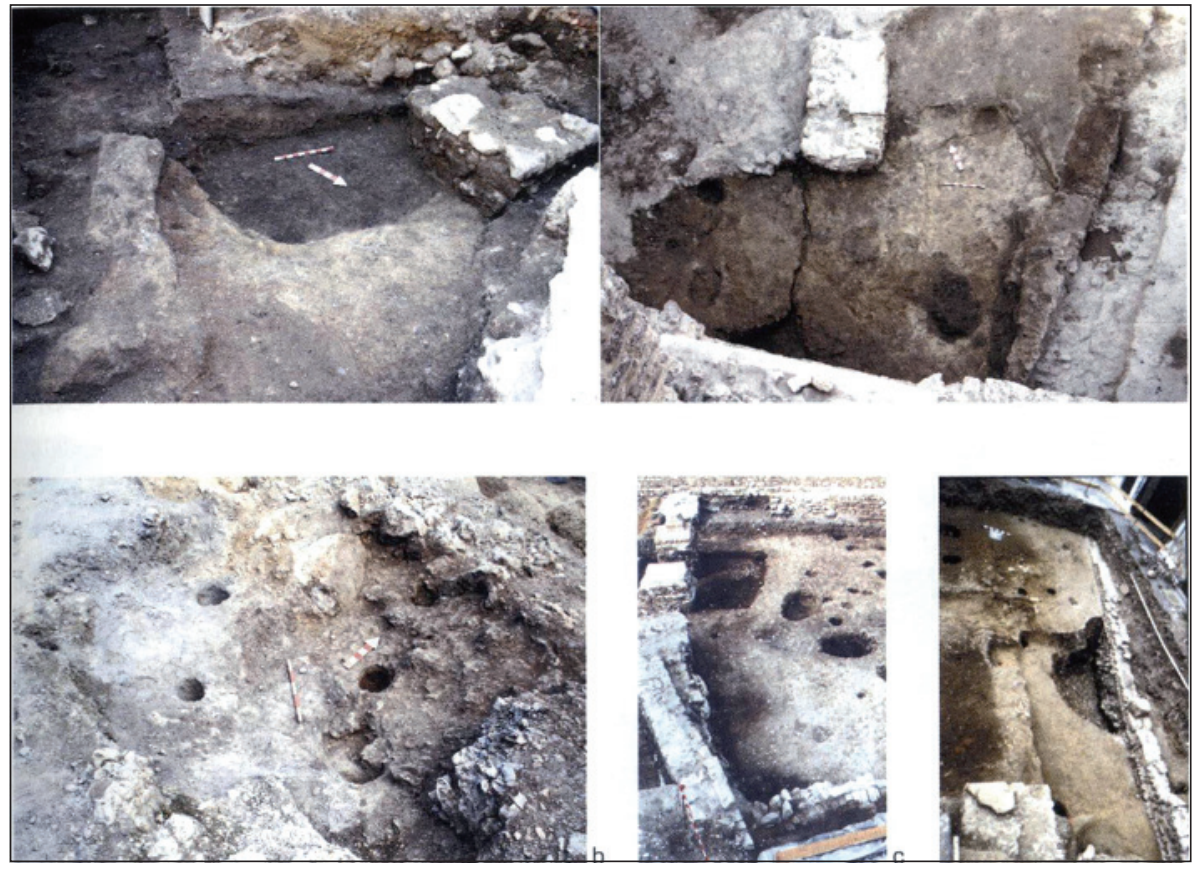

In some cases, many of the buildings constructed using the aforementioned technique of horizontal beams display considerable consistency in their plan, size and function. In the case of the village near San Agata Bolognese, residential «lots» were built all of the same size $(6 \times 9 \mathrm{~m})$, divided by an internal partition, in which, in their southern section, there was a wooden flooring, corresponding to the actual residential area proper, as is also seen at the Poviglio site. Some rural sites in low-lying plains, alongside the construction of these huts, were subjected to major processes of general redefinition of the arrangement of residential spaces. These alterations can be ascribed to important political authorities such as bishops, counts or abbots who, in a development similar to the aforementioned case in Tuscany, after the fall of the Carolingian empire began to exercise more incisive private rights over their possessions.

Another type of building has been identified among the buildings constructed using vertical posts. These are dwellings with an internal beaten earth floor that is lower than the level of the surrounding ground (fig.5). This type, in the view of several scholars, is connected to the huts in the Slav and Germanic areas, and it is believed that the Italian examples are a variation, given that in examples recorded in Italy we find the features of both these «foreign» categories combined, namely structures variously interpreted as either having a domestic function (the majority) or not (Fronza 2009; Fronza 2011; Santangeli Valenzani 2011; Brogiolo 2008). In both cases, so far we have records of 75 huts with a sunken floor, comprising a single interior space, and having a variable plan compared to similar examples in northern Europe, mostly concentrated in central and northern Italy, and datable mostly to between the 6th and 7th centuries (Fronza 2011). Only in rarer cases has the sunken floor been interpreted as a device to insulate the interior from damp (Arthur et alii, 2008). In recent years, the evidence of this type of hut, found both in urban and rural contexts, has sparked a debate between those who interpret them as a feature imported by peoples from outside Italy, ascribing a strongly ethnic significance to this type (most recently Brogiolo 2008; Valenti 2009; Fronza 2011), and others who see them as products of local traditions in their various developmental phases (Arthur 1999; Augenti 2004).

Houses made of mixed materials are usually in the form of single-room dwellings, of varying sizes. They are often rectangular, and their footings are made of stone (often with clay bonding) or other reused material, such as brick and tile (fig.6). By contrast, the elevations were made of perishable material, or wood, or earth. In contexts involving the reuse of previous Roman residential structures, especially in urban contexts, lower sections of walls could make use of part of the pre-existing wall for the whole perimeter of the house, or for part of it. In any event, this is a widespread type, especially in northerncentral Italy, both in towns and in the countryside, with some geographical areas where there is a particular concen- 


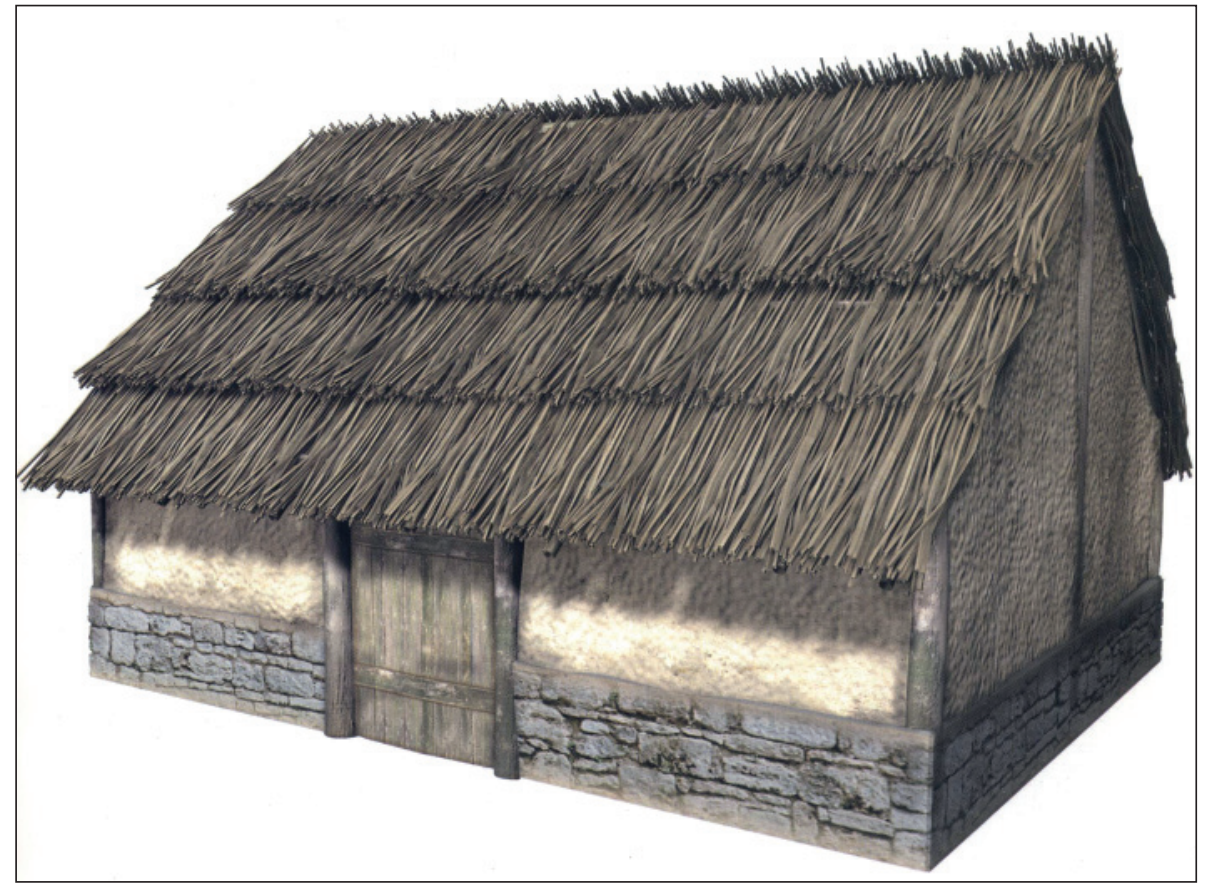

Fig. 6. Examples of huts with stone foundations, from the site of Campiglia M.ma (from Valenti 2004, p. 33, fig. 14) tration, such as Liguria. This building type is seen from the late 4 th century until the 10 th- 11 th centuries, when in Tuscany, for example, it is seen in the building phases immediately prior to the appearance of stone-built castles in the 12th century. The two huts excavated in the forum of Luni display this kind of technique, albeit with the variant of a sloping roof erected on a system of poles placed just outside the perimeter walls, instead of resting on the perimeter walls, thereby creating a sort of portico.

Homes with usually just one room, with walls made totally of pressed clay, are present especially at sites in central Italy. This is the case with houses at many centralized settlements excavated in Abruzzo (fig.1), datable to between the 7 th and the 9th centuries, inhabited by farming communities who lived off agriculture (discussed most recently by Staffa, 2005). A well-known case are the five houses excavated in Caesar's Forum in Rome (fig. 8), which, while having a stone footing incorporating reused material, had a clay wall on top of this lower section. These dwellings consisted in a single interior space, often small ( $5 \times 5 \mathrm{~m})$, on just one level, having a beaten earth floor and an internal hearth. The houses were built in the first half of the 10th century, and there are earlier examples at other sites in Lazio, such as Porto (seen mostly recently in Santangeli Valenzani 2011). To show how widespread this construction technique was in central Italy, one only has to remember that the workshops situated near the Chiesa
Maggiore at the monastery of S.Vincenzo al Volturno (fig. 1), datable to between the end of the 8th century and the first few decades of the 9th century, were built with walls of pressed clay (Hodges, Leppard, Mitchell 2011).

Among the houses that were built totally or mostly in non-perishable material, we find a building type which, having already been identified in the past, thanks to a study of documentary sources (Cagiano De Azevedo 1986b, pp.349-372), has recently been at the centre of archeological interest thanks to recent finds of material traces. These are usually larger houses compared to those built using perishable material, and have an upper floor. They also have a more complex division and function of the internal spaces. Previous analysis of written texts documenting them, in the area of Ravenna as of the 7th century at least, had allowed the identification of similar features: on the upper floor there was a dining room, and rooms for sleeping; the ground floor was designed for cooking and storage; there were annexations to the house, without roofs, and these often contained a well. Recent archeological research has brought to light structures of this type in urban contexts. Houses with an upper floor, with these distinctive features, have been found at Classe, Brescia, perhaps Milan, and Rome, all datable to a chronological period variously included between the 7 th and the later 10th centuries (Brogiolo 2008, Brogiolo 2009; Santangeli Valenzani 2011; Augenti 2010). Rome is certainly the context where this category is best attested to, thanks 
Fig. 7. Two-storey 9th century houses from Nerva's Forum, Rome (from Brogiolo 2011, p. 176, fig. 82)

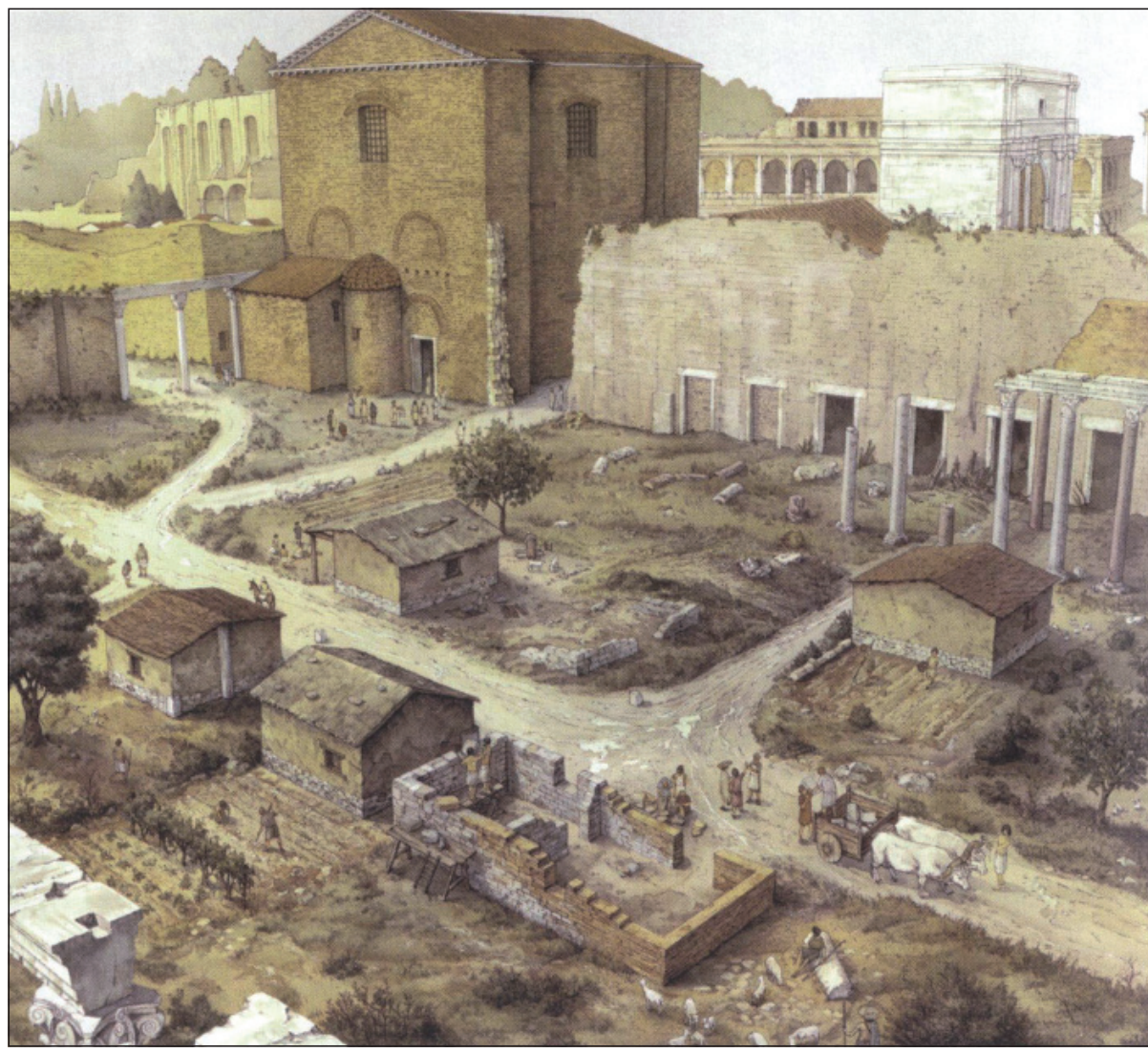

to the excavation and study of numerous examples. The first houses were found in Nerva's Forum, and were dated to the mid-9th century (fig. 7). Added to these are the building in the Roman Forum situated in the portico opposite the Basilica Emilia which, although excavated in the 19th century, has strong similarities with the example in the Nerva's Forum. Indeed, these latter examples have a rectangular plan, with walls built of reused stone blocks in the lower section, and bricks and small stones for the upper floor, access to which was via external steps. One of these examples, which later had a portico added, had annexed features: a well for water, and a drain for waste from the latrine, situated on the upper floor. Archeologists believe it is possible that other examples of this architectural type, preserved only partially in other parts of Rome, may belong to this category (see, most recently, Santangeli Valenzani, 2011 pp.75-90, with bibliography). Houses with an upper floor are also attested to in the documents: they were called solarate, or having a solarium, and existed in major urban centres such as Ravenna (Cirelli 2008) and Lucca (Belli Barsali 1973). This last example, together with those in northern Italy, confirm the widespread distribution of this building type, both in Byzantine urban areas and the Lombard area. By contrast, there are very few similar attestations for rural areas, where they are only attested to by documentary sources, although not before the later 10th century. In any event, these are always particularly significant residential contexts, connected to important monasteries, for example, such as the one in Bobbio (De Stefanis 2002, p. 40), or to castles founded by prominent political figures such as counts or bishops, as seen in Tuscany and Piedmont (Settia 2007, p.150). Added to this group are the examples cited by some documentary sources, also studied by Cagiano De Azevedo, for urban houses with masonry walls, just one storey high. These are also quite large (it is suggested that one was around 222 sq mt, Cagiano De Azevedo 1986b, p.360), but they cannot be related to the homes having restricted living space which are attested to in the archeological record, for example in Caesar's Forum, as mentioned earlier.

Towers also belong to the group of residential architectural buildings made of non-perishable material. Towers with defensive functions were present in many of the new Late Antique urban circuit walls, as well as in numerous castra in northern-central Italy (Brogiolo, Gelichi 1996; Cagnana 2001). In towns, the first changes of end use of this kind of building, with differing functions compared to 


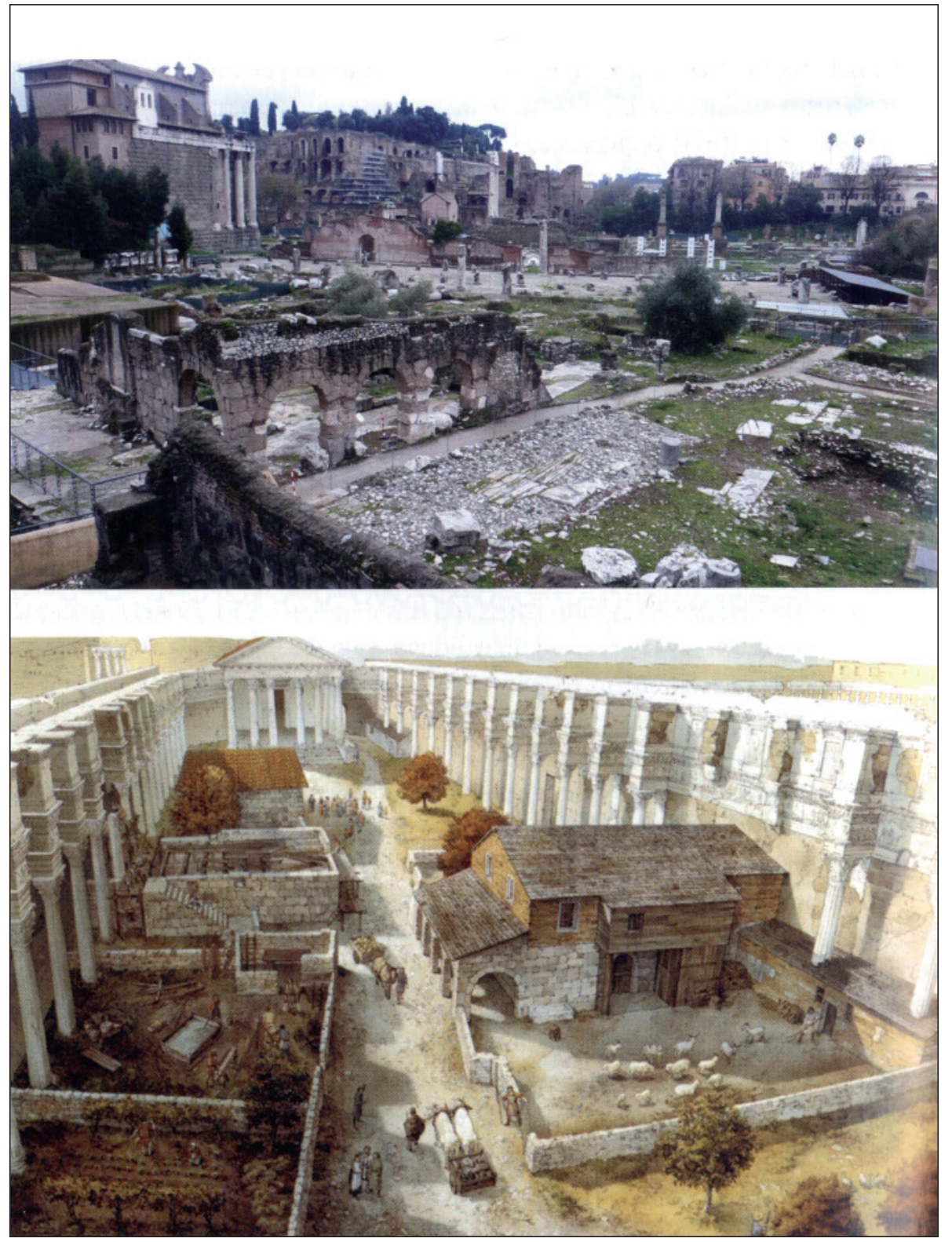

Fig. 8. 10th century houses with earthen upper walls from Caesar's Forum (from Brogiolo 2011, p. 171, fig. 77) the purely defensive functions, were connected especially to the presence of monastic communities, when towers were incorporated into some of the new monastery complexes built adjacent to outer town walls (Lusuardi Siena 1986, for instance, for examples in Milan). In the countryside, too, towers were initially associated with monastic contexts, often pre-dating the foundation of the monastery, and often used as residences and for burials $s^{4}$. As of the 10th century, urban towers began to be granted by the ruling authorities for private residential use, first to counts,

${ }^{4}$ For a more detailed analysis of the evolution of this type, only mentioned briefly here for reasons of space, see Settia 2007; for the reference to towers in urban and rural monastic contexts, see Cantino Wataghin 2000. marquesses and bishops, and later on to other persons too, not holding public office, but enjoying privileged relations with the institutions. In rural parts of Tuscany, and for much of northern central Italy, for example, only as of the second half of the 10th century do we find documentary references to the presence of a tower in castra or curtes, linked to important figures such as bishops, abbots or representatives of non-religious institutions (see Settia 2007, again; for Tuscany, see Augenti 2000). In these latter cases, one can imagine that the tower was the fixed or temporary place of residence for figures having political and economic control over these sites. This, for example, is the preliminary interpretation given to the tower recently discovered at the site of Donoratico (fig. 3), built in the 
same decades (end of 9th century, first half of 10th century) as the large hut described above (Bianchi et alii.). The tower is quadrangular, and was built into the site's first defensive circuit of stone walls, dominating an open space which the hut itself also gave onto.

As regards masonry techniques used in perimeter walls, both of the two-storey houses and the towers, we find ways of building that are differentiated, but which are often marked by the reuse of material, and by an irregular technique of wall-building, in line with the main features of early medieval construction using non-perishable material (most recently: Cagnana 2008; Cagnana 2010).

\section{EMPIRICAL KNOWLEDGE AND TECHNOLOGICAL PROCESSES}

In terms of knowledge of construction techniques, many of the kinds of houses made from perishable material, described in the previous paragraph, are the result of a local construction idiom, the product of the union of a certain natural environment, and of a particular technical environment, which developed within specific local geographical contexts over the centuries. The huts made from vertical poles in the ground, the earthen houses, or houses with walls made of stone in their lower sections are types for which there is much evidence both before and after the early medieval period ${ }^{5}$. These were certainly the result of the work of inhabitants-cum-builders, or local builders, who were fairly unspecialized, not only in connection with the technical difficulty of the individual operations but also in relation to the number of operations themselves. Knowledge of these operational chains derived from the stratification of skills handed down from one generation to the next, marked by minimal variations distributed over long spans of time.

Thus, to analyze the more complex developments in skills which exemplify diversified social and economic contexts, it is necessary to focus attention on building types that indicate abnormal features which can be related to more specialized skills, or to the work of builders who came from outside the local building cultures. This could be the case with the above-mentioned huts with sunken internal floors, which some researchers see as the import of a model by peoples from elsewhere.

By contrast, the use of specialist builders has been suggested for the huts in the Po Valley area, which have wooden beams laid on the ground level, horizontally

\footnotetext{
${ }^{5}$ On the continuity and distribution of particular types of hut, see the excellent analysis in Cataldi 1988.
}

around the outside of the building, on which the wooden superstructure was erected. This building type seems to have been very widespread in relatively short chronological periods, and to relate to a fairly consistent geographical area, including urban and rural centres (linked to important political figures). In this case, the specialists could have had the task of providing the standardized wooden elements needed for the construction of the main framework. Indeed, this technique required a more subdivided and specialized process of timber use, which had to be adapted and shaped, for successful joinery. These specialists had responsibility for the general supervision of the assembly of these elements, probably carried out together with the local inhabitants (Gelichi, Librenti 2010, p. 26).

The presence of specialized personnel can also be suggested for the construction of the two examples of huts that are typologically close to the north European longhouses. Their large size, and the construction of a gabled roof in Poggibonsi, and a pitched roof at Donoratico (fig. 3), presupposes calculations of the weight and slope of the roof requiring a certain skill in construction. The presence of only two examples, so far, of this type of construction in the area of Tuscany, and the fact they are chronologically close, inside two supposed major 'curtes' centres, could perhaps be explained as the possible import of skills from the Germanic areas with which Tuscany had intense and privileged relations, ever since the early centuries of the early medieval period, and this became more established during the 10th century, continuing right up until the end of the Ottonian dynasty ${ }^{6}$.

Unlike wood, the use of stone is linked to more specialized technological results, also due to the fact that it requires greater planning. In constructions made of nonperishable materials, like the two-storey houses described in the previous paragraph, the use of reused material seems the dominant technique used. The more complex planning that went into this kind of architecture, and the complexity inherent in the selection of this technique, as well as the transportation and reuse of salvaged material, may, however, also be indicative of the work of specialists. However, in the case of new construction materials, more recent archeological studies stress the widespread use of unquarried stones or river pebbles, as well as specially

${ }^{6}$ This kind of exchange of skills over long distances, at larger construction sites, has been suggested for the importing of a certain number of so-called cement mixers, again above all in Tuscany, three of which just predate, in the case of Donoratico, the construction of the large hut, Bianchi et alii 2012; Bianchi 2012. Close similarities between the large hut at Poggibonsi and those found in Germanic areas were already highlighted by Valenti (Valenti 2004, p. 26, n. 80). 
extracted stones, which were at times more carefully finished. These features can be seen as of the end of the 8th century, for example in the walls of some churches in Lucca (Bianchi 2008) or in the architecture of the monastery of San Vicenzo al Volturno, where rough-hewn stones can be seen taken from new quarry faces (Gobbi 2010). Despite this, the rarity of such cases has frequently led many scholars to claim that there were simplified production cycles linked to stone, owing to the loss of specialist quarry and stone-working skills. This is only partially true, especially also in light of a re-reading of the scant early medieval documents citing the work of particular skilled workers, called commacini ${ }^{7}$. These are discussed in a number of sections of the Rotari edict (643), and in particular the Memoratorio de mercedes commacinorum, attributed to the reign of Grimoaldo (662-671) or Liutprando (712-744), a sort of price list of the day. From this source, one clearly sees that there was provision for both the construction of stone walls and the creation of furnishings, such as plutei and marble slabs, in the context of groups of specialist workers. This rather vague distinction of roles suggests the presence of builders and masons who, if necessary, could also produce sculptural decoration (Lomartire 2009). This is certainly indicative of a clear reduction in the numbers of these specialists, following a considerable fall in demand, although this does not appear to be linked to a sort of technological recession.

From an analysis of tool marks on sculptural elements from the 8th to 9th centuries, one deduces that a wide range of tools were used (Lomartire 2009, pp. 179-203), similar to the range of tools used to square stones as of the 12th century (Bianchi, Parenti 1991). Accordingly, the absence of stone-working, and the consequent irregular technique, would not be due to any loss specific technological skills, since these were applied to decorative features; instead, it would seem to depend more on an economic criteria. In this way, time and energies would be saved for a work which, if carried out on large stones, could take between six and eight hours of work for each individual ashlar block (Cagnana 2000, p. 62). A similar decision was also made as regards whether to dress only some or all of the walls themselves.

For stone walls, this evidence leads us, therefore, to recognize selected production cycles, rather than simplified cycles. The selection was made by the people commissioning the building, who were interested in containing the costs of the whole building operation, an aspect which can

${ }^{7}$ On the etymology of this term, see also Mastrelli 2009. also be seen in the evident reduction in the size and plans of contemporary buildings, both private and public (Ward Perkins 1984, and most recently Augenti 2008). However, we must not consider this fact as being divorced from the differing level of perception, and the different symbolic significance, which the various parts of the building had for the person who commissioned the building, a point which we shall return to in the paragraph below.

The importing, and often also the spread, of these specialized skills regarding building in stone and wood, was also connected to the constant mobility of the groups of specialists hired at different urban and rural building sites to organize the construction, coordinating the local builders, as well as unskilled labourers (Galetti 1997, pp.100-103). In recent archeological analyses of early medieval stone masonry, it has been possible to distinguish the work of specialized builders, marked by the adoption of a technique requiring more sophisticated knowledge, from the work of hypothetical builders who looked to a more local, simplified construction technique, and who were called in to help the specialists at the construction site (Bianchi 2008). For some scholars, the disappearance, as of the end of the 8th century, of the term commacino, almost a synonym for specific technological skills, is indicative of the greater number of specialized builders ${ }^{8}$. These would have continued to work in rural areas too, as shown by recent archeological data, where some researchers believe that non-specialized builders were still predominant (see, for example, Andreolli, 2009, p.51).

\section{SOCIO-ECONOMIC STRUCTURES, MENTALITY, AND WAYS OF LIVING}

In the second section, an attempt was made to stress that the range of types of dwelling in early medieval Italy is extremely differentiated, not only in individual local contexts but also within individual sites, both large and small. In rural areas that have been studied most in northern central Italy, this characteristic seems to reflect the very variability of types of sites, also stressed in the most recent contributions giving overviews of this issue (BrogioloChavarria Arnau 2005). Indeed, at the same time as we find the well-known Tuscan model of centralized hilltop villages already forming in the course of the 7 th century (Francovich-Hodges 2003), there were residential nuclei on top of, or near, abandoned villas, inside the surviving

\footnotetext{
${ }^{8}$ Azzara, 2009, pp.20-31 stresses that in northern central Italy the term commacino was no longer used after 720 , which contrasts with the fact that it was widely used up until the 11th century in the lands of Langobardia minor.
} 
Late Antique castra, and around churches that, in turn, were often established on top of the remains of previous villas. The process of regionalization in Italy, connected to the new presence of local powers, which had such an important influence on material culture, seems therefore to also be echoed in the absence of homogenous living areas. As regards dwellings made of perishable materials, skills linked to most of the types discovered thus far seem to relate to local technical and cultural circles, and to belong to builders-cum-inhabitants, perhaps members of individual family nuclei. The fragmentation of building skills seems to reflect the reality of settlement nuclei which, generally, were devoid of a shared, community-wide culture of ways of living, marked by the simultaneous presence of individuals perhaps of different origins, and in some cases different ethnic groups (for the aforementioned hypothesis of a connection between the huts with sunken floors and peoples coming from outside). For that matter, wood seems the most suitable material for the homes of people with only a limited sense of belonging to particular communities, who only have a slight identification with the local area (on this point, see Wickham 1992), often moving from one agglomeration to another, as attested to by some early medieval written sources, including with reference to the middle centuries of the medieval period (Molinari 2010, p.13). Only on the threshold of the 10th century, when significant political powers began to be more involved in managing rural settlements, at least in northern central Italy, is it possible to identify a greater typological homogeneity, as in Po valley villages, a homogeneity that was perhaps more imposed from above than devised within the communities themselves (as would also be shown by the supposed summoning of specialized builders from outside). At other sites, in particular Tuscan hilltop villages, different building indicators were chosen by the owners to indicate their stronger presence. This is the case with the new outer walls of stone (to define the space within the site and the space outside), and religious buildings (Bianchi 2010a).

Given that recent archeological reinterpretations indicate a movement of owner-élites from the town to the countryside, especially as of the 12 th century, when the first real aristocratic residences appear atop fortified settlements, it is hard to establish an immediate connection between the size of the huts and the higher social status of its possible inhabitants. Only at the sites of Poggibonsi and Miranduolo in Tuscany does the archeological record seem to prove this link (Valenti 2004). In the other examples in Tuscany, the material evidence, which is not sufficient to back up these hypotheses, lead to an inability to claim this is a general truth ${ }^{9}$. The interpretation of the long hut at Donoratico (built a stone's throw away from the site's real privileged building, the stone-built tower) as a place of collective habitation designed for community activities, could instead be a sign of the reorganization of some rural sites, and perhaps a greater optimization and control of labour, with work performed by dependents on behalf of the owners.

By contrast, in towns and cities, the large-scale use of perishable materials, for the construction of houses of different types, has been ascribed by G.P. Brogiolo to a new social composition of the people who lived in them: immigrant farmers, perhaps forced to abandon their are fields by external threats; artisans, including those of low social status, and serfs employed in new areas of production; the settlement of new populations from outside; and a more numerous presence of soldiers (Brogiolo 2011, p. 180).

In any event, the high percentage of these types of building, linked to the use of perishable materials, attested to for this period, in towns and in rural areas, is certainly indicative of important transformations which can be interpreted at several registers.

Primarily, the economic register. Italy's economic recession, which can be seen as far back as the start of the 5 th century, is a change stressed by many scholars (most recently, for Italy: Wickham 2005; Ward Perkins 2005; Delogu 2010). A recession which, in Italy, was allegedly aggravated by the Gothic war and by the invasion of the Lombards, which it is thought accelerated that process of political and economic fragmentation. Accordingly, it is claimed that a generally poorer society was forced to make savings, both in construction material and in the size of the houses themselves, with multi-purpose spaces serving several different functions. While wide diffusion of houses made of inexpensive materials cannot be related to external cultural influences, being on such a large scale, it must necessarily be related to a greater gap between the more limited groups of those who had wealth (albeit relative) and the majority of the poorer middle to lower classes. In these homes there was no provision for extended stays. As noted by Santangeli Valenzani, people returned to these homes only to sleep at night, and to carry out basic domestic activities. The rest of the working activities, and

\footnotetext{
9 As, for example, in the case of the medium-to-large hut at Montemassi, interpreted as a place for residential dwelling and community work activities (Bruttini 2009).
} 
probably social activities too, were carried out outdoors, demonstrating the perception and function of the house, seen as a space that was «used but not lived in» (Santangeli Valenzani, 2011, p.134).

When we go to analyze houses of greater architectural prestige, built from non-perishable materials, one fact emerges clearly, namely the lesser importance of the exterior appearance of the interior spaces, enclosed within walls made of stones, or reused material, not laid in regular courses. This aspect, which does not really depend on a decline in construction skills (as we tried to demonstrate in the paragraph above), can perhaps be seen as the outcome of a different perception of homes, following a cultural change compared with the classical era, in part conveyed by the Church.

As far back as the 7th century, in his Etymologies, Bishop Isidore of Seville seems to hark back to a term found in Vitruvius, vetustas, originally indicating proportion and rhythm, to give it a new meaning. According to Tosco, this referred to a building's additional ornamentation (Tosco 1993). In the view of Isidore, therefore, the beauty of a building derives more from the magnificence and importance of the decorations applied to architecture $^{10}$. Thus, the value of architecture lay, above all inside it, and the parameter of wealth of the commissioning authority and the value inherent in the symbols associated with this, depended also on the "treasures» contained in buildings themselves, as well as on the architectural decorations ${ }^{11}$. Seen from this viewpoint, within a culture and an economy that were clearly seeing major transformations, one fully understands the reduced attention paid to the «outer shell» of these internal spaces, namely the outer facades. In addition, despite the fact that its solidity of construction was important, in many cases the outer walls were partially or totally plastered. It is possible that the high-status inhabitants of the two-storey houses in Nerva's Forum, for example, referred to this model. Those houses were built with reused material, but they had a window with a richly sculpted architrave (Santangeli Valenzani 2011, p. 135). Long-lasting material, such as stone, although reused, continued to have strong associations with power and wealth. But, in this renewed context of building work, more time had to pass until regular courses entered these building programmes, as an eloquent symbol, as happened for the architecture at the height of the

\footnotetext{
${ }^{10}$ As well as Tosco, on the subject of the change in the rhetoric of building, see also Wickham 1988.

${ }^{11}$ On the concept of wealth in early medieval Italy, see most recently Gelichi, La Rocca 2004 and Devroey, Feller, Le Jan 2010.
}

12th century (Bianchi 2010b). Moreover, one must not forget that the Church itself, in this case by means of the $10^{\text {th }}$-century writings of Bishop Raterio of Verona, still set out a series of features as distinctive elements of the dives, at least for post-Carolingian élite groups. Rather than houses themselves, these related above all to external, «mobile» manifestations of wealth, such as clothing, jewellery, and furs (La Rocca 2004, p.131). This, of course, does not mean that there was no perception of houses as an indicator of social standing. Proof of this lies in the differing terms used to refer to houses which we find in the written sources in the Lombard area. These signify a diversity of status among inhabitants, with the palatium at the top of the hierarchy, followed by a domus or sala, and in last place the curtis and casa (Jarnut 2005, p.344). This distinction was very much present also in the writings of Bishop Isodore of Seville who, in the 7th century, differentiated the domus from the tuguria and from capannae (Brogiolo 2011, p.164), as well as in the documents of the 7th-8th century Ravenna Code, in which the domus is distinguished from the mansio of the lower social classes.

However, we have seen that, whilst maintaining the same definition, and perhaps, according to Jarnut, the same conceptual meaning as in Late Antiquity (Jarnut 2005, p. 344), the early medieval domus has very different characteristics: a smaller plan, an adjacent courtyard, sometimes a portico, and above all greater verticality, owing to the presence of an upper storey (often called a solarium). However, despite these differences, according to some scholars the connection with the former past seems clear, given that, in Late Antiquity, houses with a vertical elevation, and an upper storey, as Ellis underlines, are present in villages in Syria, Egypt, the bishop's palace at Bosra, and the villa of San Giovanni at Ruoti (Ellis 2007, p.15), and we could also add in the houses of the village of Caucana on the southern coast of Sicily (Santangeli Valenzani 2011, pp.63-64).

The earliest early medieval documents describing these domus and linking them to owners having a high social standing date from the end of the 7th century, and refer to the area around Ravenna. They thus relate to the an area with Byzantine domination. It is yet to be understood why this type of house had a certain success among élite groups, both in this area and in the Lombard area. The choice of building model which, in one form or another, had an important connection with the Late Antique period, despite referring to a more compact architectural module, with the result that it was less expensive and more suited to the economy of the day, 
could have acquired further prestige also perhaps owing to the legitimization of the Church itself. In his earlier writings, Cagiano de Azevedo noted that houses that had a solarium were preferred by church communities in central and northern Italy (De Azevedo 1986c, p.123). More recently, De Jong noticed, in ecclesiastical writings, an almost sacred meaning given to the solarium, deriving, according to Isidore of Seville, from sol (sun), standing for a place of purification and spiritual closeness with the divine. This second floor was allegedly given further significance in the Carolingian period, when, in imperial palaces, the solarium was perceived as a place specially set aside for the Emperor or king to rest, becoming an important part of the topography of royal power (De Jong 2008, p. 278). Thus, it is possible that the fact it was laden with these meanings was understood by contemporary inhabitants of early medieval towns, where a higher number of houses with a solarium are documented. The tower itself, owing to its vertical height, came to have a more specific significance in terms of residential dwellings, as of the 8th century, starting from urban monasteries (in what is no coincidence), and began thereby to see a success which was to transform it into the most widespread building model in the middle centuries of the medieval period.

By contrast, given the lack of more tangible data, it is harder to link the diffusion of this model to changes in the family structure, kin relationships, and relationships in general, compared with the Roman era. At the moment it is best to analyze this aspect by means of other material indicators, such as the form and characteristics of burials (for the most recent work, see: La Rocca 2011; Barbiera 2012).

The documentary and material evidence certainly show us a drastic reduction in the number of interior spaces designed for the public and professional activities of the dominus, which, by contrast, in the Late Antiquity period were carried out in special parts of his residence, and which required a greater hierarchy of the spaces themselves. Moreover, it is clear that the family nucleus had a considerably lower number of servants. In the past, such servants sometimes occupied large portions of the Late Antique domus (Ellis 2007, pp. 8-10).

\section{IN CONCLUSION}

Recent research in urban and rural areas shows similar trends in ways of living throughout Italy, regardless of areas that were under differing forms of power. There was a widespread and constant use, throughout the early medieval period, of perishable materials, associated with fairly simple house types, marked by a multifunctional use of the interior space. This is unquestionably an index of a general economic recession, which forced people to use less expensive materials, and simpler technological procedures. Despite the extreme variety of types, and the absence of homogeneous construction areas, especially in the initial centuries of the early medieval period, there is an undoubted preponderance of simpler houses made of perishable materials, where most of the population, consisting in the medium to low classes, lived. Meanwhile, there are fewer references in written sources, and in the archeological record, of houses belonging to the middle and upper classes. This absence cannot be attributed to a change in the mentality of self-representation, given that there was full awareness in Lombard-dominated areas, as we are told by the differing terminology in written sources, of the differing types of houses in relation to the social level, and as representing social status. Nor must we forget the presence, albeit numerically small, of specialists who were able to carry out complex technological procedures. This fact would thus seem to confirm the suggestion advanced by Jarnut, namely the considerably reduced number of members of these élite groups, and the resultant reduced diffusion of wealth (Jarnut 2005, p. 346), as also shown by decisions aimed at investing in differing parts of the house (with greater economies made, for example, on the characteristics of the exterior of walls). Another fact that emerges is the reference, in the case of higher-status houses, to Late Antique tradition, in the context of a process of legitimization of one's status which, throughout Italy, was achieved in the form of a link with the past, shown also, in some instances, by the frequent custom of reusing old material. We have also stressed that the Church itself perhaps had a prominent role in codifying certain reference models, which probably had an important impact on decisions relating to building in relation to forms of self-representation. For these elite groups, the choice of house types displaying smaller plans and areas given over almost exclusively to living could be a further index of a marked socio-economic change, within an urban context that was undergoing a transformation. The fact that the typically Late Antique conception of the domus, as a structure designed not only for domestic life but also having spaces for professional meetings, business, and commerce, was no longer current presupposes that most of these activities were to be conducted away from the house, in a town which became, in the early medieval period, the site of shops and 
workshops, linked to production on a smaller scale that was controlled by centralized and local authorities, both secular and ecclesiastical.

The other fact which can be deduced from an overview of modes of living and places of living is the scant presence of socially representative houses in rural parts of Italy. One rarely finds examples of superior building work associated with the large number of huts in residential sites on hilltops or flat plains. This is proof of the degree to which the aristocracy was deeply rooted in the towns, which in the early medieval period continued to play an important role as political and economic centres. Excluding isolated episodes, it is only after the break-up of the Carolingian empire, namely after the end of the 9th century, that stronger signs are seen, in rural areas and in towns, of important changes which necessarily also affected ways of living. A gradual process of reorganization of agricultural holdings, with the start of more incisive exploitation of the land by the elite (see most recently Delogu 2012, pp. 104-105) coincided with the appearance not only of new stone-built outer walls and churches on hilltop sites, but also of more prominent stone buildings, such as towers, as well as more complex wooden building models, linked to a possible planning of domestic living space, as in the case of the villages in the Po Valley. In the towns, a greater liveliness in the social composition, together with an increase in wealth, led to a higher number of higher-status houses, as shown by Rome, above all. This is confirmation of a slow, gradual economic recovery, which seems to reach its height only in the 12th century. Indeed, it is no coincidence that this is the time when a variety of housing solutions are documented, also connected with greater investment in building materials, and in their preparation. This would perhaps be one of the clearest demonstrations, together with other material parameters, of the real economic boom of medieval Italy, as recently suggested by some scholars (Wickham 2010).

\section{Bibliography}

Andreolli B., 2009, Misure e mercedi. Costo e valutazione del lavoro nel Memoratorium de mercedes commacinorum, in I magistri commacini, pp.35-52. Andrews D., 1978, (Viterbo) Tuscania, colle S. Pietro, in S. Nepoti (eds.), Schede 1977, "Archeologia Medievale», V, pp.487.

Arthur P., 1999, Grubenhauser nella Puglia bizantina. A proposito di recenti scavi a Supersano (LE), "Archeologia Medievale», XXVI, pp.171-177.

Arthur P., Fiorentino G., Imperiale M.L., 2008, L'insediamento in loc. Scorpo (Supersano, LE) nel VII-VIII secolo. La scoperta di un paesaggio altomedievale, "Archeologia Medievale", XXXXV, pp.365-380.

Augenti A., 2000, Dai castra tardoantichi ai castelli del secolo X: il caso della Toscana, in R. Francovich, M. Ginatempo (eds.), 2000, Castelli. Storia e archeologia del potere nella Toscana medievale, Firenze, pp.25-66.
Augenti A., 2004, Fonti archeologiche per l'uso del legno nell'edilizia medievale in Italia, in Galetti P. (eds.), Civiltà del legno: per una storia del legno come material per costruire dall'antichità ad oggi, Bologna, pp.37-69.

Augenti A., 2008, A tale of two cities. Rome and Ravenna between 7th and 9 th century $A D$, in S. Gasparri (eds.), 774. Ipotesi su una transizione, pp. 175198.

Augenti A., 2010, Tutti a casa. Edilizia residenziale in Italia centrale tra IX e X secolo, in P. Galetti (eds.), pp. 127-152.

Azzara C., 2009, Magistri commacini, maestranze e artigiani nella legislazione longobarda, in I magistri commacini. pp.19-34.

Barbiera I., 2012, Memorie sepolte. Tombe e identità nell'alto medioevo (secoli VVIII), Roma-Urbino.

Barker G., Hodges R., Wade K., 1980, Excavations ad D85 (Santa Maria in Civita): an early medieval hilltop settlement in Molise, "Papers of the British School at Rome», XLVIII, pp.70-124.

Belli Barsali I., 1973, La topografia di Lucca nei secoli VIII-XI, Atti del V Congresso Internazionale di Studi sulliAlto Medioevo, Spoleto, pp.461-554.

Bianchi G., 2008, Costruire in pietra nella Toscana medievale. Tecniche murarie dei secoli VIII-inizio XII, «Archeologia Medievale», XXXV, pp.23-38.

Bianchi G., 2010a, Dominare e gestire un territorio. Ascesa e sviluppo delle signorie forti' nella Maremma toscana del Centro Nord tra Xe metà XII secolo, in A. Molinari (eds.), pp. 93-104.

Bianchi G., 2010b, Archeologia dell'Architettura e indicatori materiali di storia sociale: il caso toscano e l'Italia centro Nord tra IX e XII secolo, "Archeologia dell'Architettura", XV, pp. 205-210.

Bianchi G., 2012, Miscelare la calce tra lavoro manuale e meccanico. Organizzazione del cantiere e possibili tematismi di ricerca, in G. Bianchi (eds.), Dopo la calcara: la produzione della calce nell'altomedioevo. Nuovi dati da Lazio e Toscana fra ricerca sul campo, archeologia sperimentale e archeometria, "Archeologia dell'Architettura", XVI, pp. 9-18.

Bianchi G., Parenti R., 1991, Gli strumenti degli scalpellini toscani. Osservazioni preliminari, in Le pietre nell'architettura:strutture e superfici, Atti del Convegno di Studi di Bressanone, 25-28 giugno 1991, Padova, pp.139-149.

Bianchi G. Chiarelli N., Crisci, G.M. Fichera G., Miriello D., 2012, Archeologia di un cantiere curtense: il caso del castello di Donoratico tra IX e X secolo. Sequenze stratigrafiche e analisi archeometriche, in G. Bianchi (eds.), Dopo la calcara: la produzione della calce nell'altomedioevo. Nuovi dati da Lazio e Toscana fra ricerca sul campo, archeologia sperimentale e archeometria, "Archeologia dell'Architettura", XVI, pp. 34-50.

Brogiolo G.P., (eds.) 1984, Archeologia urbana in Lombardia, Modena.

Brogiolo G.P. (eds.), 1994, Edilizia abitativa altomededievale in Italia centrosettentrionale, Mantova.

Brogiolo G.P., 2008, Aspetti e prospettive di ricerca sulle architetture altomedievali tra VII e X secolo, "Archeologia Medievale», XXXV, pp. 9-22.

Brogiolo G.P., 2009, Architetture e tecniche costruttive in età longobarda: $i$ dati archeologici, in I magistri commacini. pp.211-238.

Brogiolo G.P., 2011, Le origini della città medievale, Mantova.

Brogiolo G.P., Gelichi S., 1996, Nuove ricerche sui castelli altomedievali in Italia settentrionale, Firenze.

Brogiolo G.P., Gelichi S., 1998, La città nell'alto medioevo italiano, Bari.

Brogiolo G.P., Chavarria Arnau A., 2005, Aristocrazie e campagne nell'Occidente da Costantino a Carlo Magno, Firenze.

Bruttini J., 2009, La formazione dell'insediamento accentrato nella valle del Bruna: il caso di Montemassi, Grosseto (VIII-X secolo), in G.Volpe, P.Favia (eds.), Atti del V Congresso Nazionale di Archeologia Medievale, Firenze, pp. 319-325.

Cagiano De Azevedo M., 1986a, Due «case» longobarde in Tuscia, in Fonseca, Adamesteanu, D’Andria, pp. 391-394.

Cagiano De Azevedo M., 1986b, Le case descritte dal Codex traditionum ecclesiae ravennatis, in Fonseca, Adamesteanu, D'Andria, pp.349-372.

Cagiano De Azevedo M., 1986c, Laubia, in Fonseca, Adamesteanu, D’Andria, pp. 111-144.

Cagnana A., 2000, Archeologia dei materiali da costruzione, Padova.

Cagnana A., 2001, Le strutture del castello. Planimetria, dimensioni, organizzazione degli spazi: un'analisi comparativa con $i$ castra dell'Italia settentrionale, in T. Mannoni, G. Murialdo (eds.), S.Antonino. un insediamento fortificato nella Liguria bizantina, Firenze, pp.101-118. 
Cagnana A., 2008, Maestranze e opere murarie nell'alto Medioevo: tradizioni locali, magistri itineranti, importazione di tecniche, "Archeologia Medievale», XXXV, pp. 39-54.

Cagnana A., 2010, Materiali da costruzione e cicli produttivi tra IX e X secolo, in P. Galetti (eds.), pp. 171-172.

Cantino Wataghin G., 2000, Monasteri tra VIII e IX secolo: evidenze archeologiche per l'Italia settentrionale, in C. Bertelli, G. P. Brogiolo (eds.), Il futuro dei Longobardi. L'Italia e la costruzione dell'Europa di Carlo Magno, Milano, pp. 129-142.

Cataldi G. (eds.), 1988, Le ragioni dell'abitare, Firenze.

Cirelli E., 2008, Ravenna: archeologia di una città, Firenze.

Comba R., 2011, A partire da Elio Conti per tornare a Elio Conti «alla luce dell'archelogian: Riccardo Francovich e il dibattito sull'incastellamento (19731988), in Riccardo Francovich e I grandi temi del dibattito europeo, Firenze, pp. 47-52.

De Jong M., 2008, Charlemagne's balcony: the solarium in Ninth-Century narratives, in J.R. Davis, M. McCormick (eds.), The long morning of medieval Europe, Padstow, pp. 277-290.

De Minicis E. (eds.), 2008, Insediamenti rupestri di età medievale: abitazioni e strutture produttive. Italia centrale e meridionale, Spoleto.

De Stefanis E., 2002, Il monastero di Bobbio in età altomedievale, Firenze.

Delogu P., 2010, Le origini del Medioevo, Roma.

Delogu P., 2012, L'ambiente altomedievale come tema storiografico, in Nanni P. (eds.), Agricoltura e ambiente attraverso l'età romana e l'alto medioevo, Quaderni della Rivista di Storia dell'Agricoltura, 8, Firenze, pp. 67-108.

Devroey J.-P., Feller L., Le Jan R. (eds.), Les élites et la richesse au Haut Moyen Age, Turnhout, 2010.

Ellis S., 2007, Late antique housing and the use of residential buildings: an overview, in L. Lavan, L. Ozgenel (eds.), Housing in Late Antiquity. Fron palace to shop, Leiden-Boston, pp. 1-22.

Fonseca C. D., Adamesteanu D., D’Andria F. (eds.), 1986, Casa, città e campagna nel tardo antico e nell'alto medioevo. Scritti di Michelangelo Cagiano de Azevedo, Lecce.

Francovich R. (eds.), 1985, Scarlino I. Storia e territorio, Firenze.

Francovich R., Milanese M. (eds.), 1990, Lo scavo archeologico di Montarrenti e i problemi dell'incastellamento medievale. Esperienze a confronto, Firenze.

Francovich R., Hodges R., 2003, Villa to village. The transformation of the Roman Countryside in Italy, c. 400-1000, Duckworth, London.

Fronza V., 2009, La Grubenhaus nell'Altomedioevo europeo, in G.Volpe, P.Favia (eds.), Atti del V Congresso Nazionale di Archeologia Medievale, Firenze, pp. 36-39.

Fronza V., 2011, Edilizia in materiali deperibili nell'alto medioevo italiano: metodologie e casi di studio per un'agenda della ricerca, "Post Classical Archaeologies", I, pp. 95-138.

Fronza V., Valenti M., 1996, Un archivio per l'edilizia in materiale deperibile nell'altomedioevo, in M. Valenti (eds.), Poggio Imperiale a Poggibonsi (Siena). Dal villaggio di capanne al castello di pietra. I. Diagnostica archeologica e campagne di scavo 1991-1994, Firenze, pp. 159-218.

Galetti P., 1994, Le tecniche costruttive tra VI e X secolo, in R. Francovich, G. Noyè (eds.), La storia dell'alto medioevo italiano (VI-X secolo) alla luce dell'archeologia, Firenze, pp.467-478.

Galetti P., 1997, Abitare nel Medioevo. Forme e vicende dell'insediamento rurale nell'Italia altomedievale, Firenze.

Galetti P. (eds.), 2010, Edilizia residenziale tra IX-X secolo, Firenze.

Gelichi S., 1997, Introduzione all'Archeologia Medievale, Roma.

Gelichi S. (eds.), 2003, Vivere nel Medioevo. Un villaggio fortificato del X secolo nella Pianura Padana, Guida alla Mostra archeologica.

Gelichi S., La Rocca C., (eds.), 2004, Tesori. Forme di accumulazione della ricchezza nell'alto medioevo (secoli V-XI), Roma.

Gelichi S. Librenti M., 2010, Edilizia abitativa tra IX e $X$ secolo nell'Italia settentrionale: stato della questione, in P. Galetti (eds.), pp. 215-220.

Gobbi A., 2010, San Vincenzo al Volturno. Approvvigionamento e lavorazione del materiale lapideo delle murature, in P. Galetti (eds.), pp. 153-170.

Gruppo Ricerche Genova, 1974a, Campagna di scavo nel villaggio altomedievale abbandonato di Savignone, "Notiziario di Archeologia Medievale», 31-1-1974.

Gruppo Ricerche Genova, 1974b, Scavi nel villaggio e sepolcreto altomedievale di Luscignano, «Notiziario di Archeologia Medievale», 31-1-1974.
Hodges R., Leppard S., Mitchell J., 2011, San Vincenzo Maggiore and its workshops, London.

I magistri commacini. Mito e realtà del Medioevo Lombardo, Atti del XIX Congresso internazionale di studio sull'alto medioevo, Varese- Como, 23-25 ottobre 2008 .

Jarnut J., 2005, Dove abitavano le aristocrazie longobarde?, in G.P. Brogiolo, A. Chavarria Arnau, M. Valenti (eds.), Dopo la fine delle ville: le campagne dal VI al IX secolo, Mantova, pp. 343-348.

La Rocca C., 2004, Tesori terrestri, tesori celesti, in Gelichi, La Rocca (eds.), pp. 123-142.

La Rocca C. (eds.), 2011, Donne e uomini, parentela e memoria tra storia e archeologia, "Archeologia Medievale», XXXVIII, pp. 9-82.

Lomartire S., 2009, Commacini e marmorarii. Temi e tecniche della scultura tra VII e VIII secolo nella Longobardia maior, in I magistri commacini, pp. 151210

Lusuardi Siena S., 1986, Milano: la città nei suoi edifici. Alcuni problemi, in Atti del X Congresso Internazionale di Studi sull'Alto Medioevo, Spoleto, pp. 209-240.

Mannoni T., 1976, L'analisi delle tecniche murarie medievali in Liguria, in Atti del I Colloquio Internazionale di Archeologia Medievale, Palermo, Erice, pp. 291-300.

Mannoni T., Poleggi E., 1974 Fonti scritte e strutture medievali del Castello di Genova, "Archeologia Medievale», I, pp. 171-194.

Mastrelli C.A., 2009, Magistri commacini: la questione linguistica e un esame del lessico tecnico, in I magistri commacini, pp. 95-150.

Molinari A. (eds.), 2010, Mondi rurali d'Italia: insediamenti, struttura sociale, economie. Secoli X-XIII, "Archeologia Medievale», XXXVII, pp. 11-284.

Molinari A., 2010, Introduzione, in A. Molinari (eds.), pp. 11-13.

Parenti P., 1994, Le tecniche costruttive tra VI e X secolo: le evidenze materiali, in R. Francovich, G. Noyè (eds.), La storia dell'alto medioevo italiano (VI-X secolo) alla luce dell'archeologia, Firenze, pp. 479-498.

Saggioro F., 2010, Abitati altomedievali in legno nella pianura veronese: problemi e temi della ricerca, in P. Galetti (eds.), pp. 75-90.

Santangeli Valenzani R., 2011, Edilizia residenziale in Italia nell'altomedioevo, Roma.

Staffa A.R. 2005, Paesaggi e insediamenti rurali dell'Abruzzo adriatico tra Tardoantico e Altomedioevo, G. Volpe, M. Turchiano (eds.), Paesaggi e insediamenti rurali in Italia Meridionale tra Tardoantico e Altomedioevo, Bari, pp. 39-126.

Settia A. A., 2007, Erme torri. Simboli di potere fra città e campagna, CuneoVercelli.

Tosco C., 1993, Isidoro di Siviglia e l'architettura dell'Alto Medioevo, "Studi Storici", XXXIV, n.1, pp. 95-119.

Valenti M. (eds.), 1996, Poggio Imperiale a Poggibonsi (Siena). Dal villaggio di capanne al castello di pietra. I. Diagnostica archeologica e campagne di scavo 1991-1994, Firenze.

Valenti M., 2004, L'insediamento altomedievale nelle campagna toscane. Paesaggi, popolamento e villaggi tra VI e X secolo, Firenze.

Valenti M., 2007, La trasformazione del villaggio in curtis nel periodo franco. IX-X secolo, in Francovich R., Valenti M. (eds.), 2007, Poggio Imperiale a Poggibonsi. Il territorio, lo scavo, il parco, Milano, pp. 107-114.

Valenti M., 2009, Ma I 'barbari' sono veramente arrivati in Italia?, in G.Volpe, P.Favia (eds.), Atti del V Congresso Nazionale di Archeologia Medievale, Firenze, pp. 25-30.

Ward-Perkins B., 1981, Two Byzantine houses at Luni, «Papers of the British School at Rome», XLIX, pp. 91-98.

Ward Perkins B., 1984, From classical antiquity to the Middle Ages. Urban public building in northern and central Italy, AD 300-850, Oxford

Ward-Perkins B., 1985 La città tardo antica e altomedievale, in Luni. Guida archeologica, Sarzana, pp. 48-51.

Ward-Perkins B., 2005, The fall of Rome and the end of civilization, Oxford.

Wickham C., 1988, L'Italia e l'alto Medioevo, "Archeologia Medievale», XV, pp. 105-124.

Wickham C. 1992, Frontiere di villaggio in Toscana nel XII secolo, in Castrum 4. Frontière et peuplement dans le monde Méditerranéen au Moyen Âge, RomeMadrid, pp. 239-251. 
Wickham C., 2005, Framing the Early Medieval Age. Europe and the Mediterra-

Recibido: 3 de julio de 2012 nean 400-800, Oxford.

Wickham C., 2010, Archeologia e mondi rurali: quadri di insediamento e sviluppo economico, in Molinari A. (eds.), pp. pp. 277-284. 